\title{
The 1513 Monte Crenone rock avalanche: numerical model and geomorphological analysis
}

\author{
Alessandro De Pedrini, Christian Ambrosi, and Cristian Scapozza \\ Institute of Earth Sciences, University of Applied Sciences and Arts of Southern Switzerland (SUPSI), \\ Campus Mendrisio, 6850 Mendrisio, Switzerland \\ Correspondence: Alessandro De Pedrini (alessandro.depedrini@supsi.ch)
}

Received: 28 February 2021 - Revised: 12 October 2021 - Accepted: 19 October 2021 - Published: 11 January 2022

\begin{abstract}
As a contribution to the knowledge of historical rockslides, this research focuses on the historical reconstruction, field mapping, and simulation of the expansion, through numerical modelling, of the 30 September 1513 Monte Crenone rock avalanche. Earth observation in 2-D and 3-D, as well as direct in situ field mapping, allowed the detachment zone and the perimeter and volume of the accumulation to be determined. Thanks to the reconstruction of the post-event digital elevation model based on historical topographic maps and the numerical modelling with the RAMMS::DEBRISFLOW software, the dynamics and runout of the rock avalanche were calibrated and reconstructed. The reconstruction of the runout model allowed confirmation of the historical data concerning this event, particularly the damming of the valley floor and the lake formation up to an elevation of $390 \mathrm{~m}$ a.s.l., which generated an enormous flood by dam breaching on 20 May 1515, known as the "Buzza di Biasca".
\end{abstract}

\section{Introduction}

Massive rockslides and rock avalanches are natural events with high destructive potential that can have a devastating impact on a territory's economic and social fabric. Therefore, even if such phenomena are rare, they cannot be considered negligible as natural hazards (Hungr and Evans, 2004). The term rockslide was adopted from the renowned slope movement classification of Varnes (1978). This term indicates phenomena developed in rock slopes, governed by shear strain and displacement along one or several surfaces. The dynamics of a rockslide, in the presence of $10^{5}$ or $10^{6} \mathrm{~m}^{3}$ of displaced rock and rapid movements, can evolve into a flow (Varnes, 1978). In this context, the term flow refers to a motion of debris on steep slopes, liquefied because of the low cohesion, that may advance well beyond the foot of the slopes. In the review of Hungr et al. (2001) of the classification of the landslides, the term rock avalanche is defined as an extremely rapid, massive, flow-like motion (semicoherent flowing mass) of fragmented rock from a large rockslide or rockfall, with a volume $>1 \mathrm{hm}^{3}$.

Considering the rockslides' and rock avalanches' distribution in the Alps (see von Poschinger, 2002), these phenomena seems to be more frequent in the central part of the Alps, particularly in the Pennine Alps and in the Lepontine Alps (between Switzerland and Italy), and in the Western Rhaetian Alps (between Switzerland, Italy and Austria), with regions classified according to the International Standardized Mountain Subdivision of the Alps (Marazzi, 2005). Considering the temporal framework of these events, several well-known rockslides fell during the modern and contemporary periods, i.e. after 1492 CE (e.g. Bonnard, 2006; von Poschinger, 2002): 1513, the Monte Crenone rock avalanche (Canton of Ticino, Switzerland); 1618, the Piuro rock avalanche (Province of Sondrio, Italy); 1806, the Arth-Goldau rock avalanche (Canton of Schwyz, Switzerland); 1881, the Elm rock avalanche (Canton of Glarus, Switzerland); 1987, the Val Pola rock avalanche (Province of Sondrio, Italy); and 1991, the Randa rock avalanche (Canton of Valais, Switzerland).

Although it may seem surprising, numerical modelling has focused on prehistoric (i.e. before the Roman period) rockslides and rock avalanches rather than on historical (since the Roman period, particularly those prior to the 20th century) events, perhaps because the most recent events are better documented or were directly observed. Staying exclusively 
in the Swiss Alps, recent reconstruction and modelling of prehistoric rockslides have concerned for example the Flims rock avalanche (Canton of Graubünden, ca. 8200 cal BP; von Poschinger, 2011), the Sierre rock avalanche (Canton of Valais, ca. 9550 cal BP; Pedrazzini et al., 2013) and the Chironico rock avalanche (Canton of Ticino, ca. $13500 \mathrm{cal} \mathrm{BP}$; Claude et al., 2014).

In order to contribute to the knowledge of historical rockslides, this research has focused on the historical reconstruction, field mapping, numerical modelling, and analysis of the geomorphological consequences of the Monte Crenone rock avalanche (MCRA) of 30 September 1513. These investigations also aim at improving the employment of historical and archaeological information in rock avalanche reconstruction and numerical modelling. Within this framework, the four objectives of this contribution include both the historical and geological reconstruction of the MCRA and the historical and geomorphological analysis of the consequences in the decades and centuries following the event and can be expressed as follows: (1) define the detachment zone and the perimeter and volume of the accumulation employing 2-D and 3-D Earth observations, as well as direct in situ field mapping; (2) reconstruct a post-event digital elevation model (DEM) based on historical topographic map analysis and a pre-event DEM by the subtraction of the fallen volume; (3) reconstruct the dynamics and runout of the MCRA thanks to a numerical model calibration; and (4) define the sediment cascade and budget generated by the MCRA, with particular interest in the damming of the valley floor and the subsequent Lake Malvaglia formation, which generated the enormous flood by dam breaching known on the southern side of the Alps as the "Buzza di Biasca" (for detail, see Sect. 2.1).

\section{Study area}

\subsection{The Monte Crenone rock avalanche}

The MCRA, which occurred at the beginning of the modern period (1492-1798 CE) on 30 September 1513, was one of the biggest rock avalanches to have fallen on the southern side of the Alps in historical times (von Poschinger, 2002; Gruner, 2006). Generated from the collapse of part of the west side of Pizzo Magn (2329 m a.s.l., also known as Monte Crenone), above Biasca, it was at the origin of the most significant natural event that indelibly marked the Ticino valley between Biasca and Lake Maggiore, the Buzza di Biasca of 20 May 1515 (Bonnard, 2004; Scapozza et al., 2015). The tens of cubic hectometres of the rock avalanche deposit dammed the river Brenno in the lower Blenio Valley (today's locality is named the Büza di Biasca) and caused the formation of a temporary lake of $130 \mathrm{hm}^{3}$ that submerged the village of Malvaglia up to the height of half the bell tower (Fig. 1). The sudden collapse of the debris dam generated a catastrophic inundation, known as the Buzza di Biasca, which destroyed the village of Biasca, flooded the town of
Bellinzona and devastated the Ticino floodplain up to Lake Maggiore (Scapozza et al., 2015). Although the Buzza di Biasca has been documented from a historical point of view (e.g. Franscini, 1849; Nessi, 1854; Motta, 1915; Pometta, 1928; Grossi, 1986; Piffaretti and Luchessa, 2011; Rossetti and Rossetti-Wiget, 2013; Viganò, 2013; De Antoni et al., 2016), little or nothing has been published regarding the causes and consequences of the MCRA, with the exception of a historical compendium of scientific studies covering the 1862-1998 period (Rossetti and Rossetti-Wiget, 2013; see Sect. 2.2).

While there is little doubt about the precise date of the Buzza di Biasca (e.g. Viganò, 2013; Scapozza et al., 2015), the exact chronology of the MCRA is much more uncertain, probably partly as a consequence of the succession of events that occurred from the 13th century leading to the rock avalanche of the beginning of the 16th century (for a historical overview, see Scapozza et al., 2015; De Antoni et al., 2016). For several authors of the 18th and 19th centuries, such as Johann Jacob Leu, Johann Conrad Füesslin, Beat Fidel von Zurlauben, Johann Gottfried Ebel and Luigi Lavizzari (discussed in Bolla, 2010, and in Scapozza, 2014, with possible information transfer from one work to the other), the MCRA took place in 1512. Atanasio Donetti in 1860 and Alfonso Toschini in 1905, for whom the rock avalanche was generated by an earthquake, indicate the dates of 30 September 1512 and 16 October/30 November 1512, respectively (Bolla, 2010; Scapozza, 2014). Cesare Bolla proposed in 1889 the date of 28 September 1515 (Bolla, 1993), whereas according to Plinio Bolla other unspecified opinions placed the MCRA on 17 October 1511, 30 September 1512, 28 September 1513 or 30 September 1513 (Bolla, 1931).

The most evident traces of the MCRA are today visible in the lower part of the Blenio Valley, where the valley floor morphology is dominated by the impressive debris accumulation generated from the rock avalanche. These loose materials were exploited in the northern part of the accumulation, first as a quarry for inert material used mainly for the construction of the national highway crossing the Canton of Ticino from Chiasso to Airolo. In recent times, where the construction material had been removed in the past, the excavation materials from the New Rail Link through the Alps (NRLA, also known as AlpTransit) were deposited. The alluvial floodplain between Malvaglia and Loderio also formed after 1515 thanks to the accumulation of fluvial deposits coming from the river Brenno and the Orino and Lesgiüna streams; this sector is today known as "Bolla di Loderio" and is recognized in the Swiss federal inventory of alluvial zones of national importance (object no. 150).

\subsection{Previous studies}

Vom Rath (1862) described the MCRA as one of the major events of its type in the Alps, covering a surface of al- 


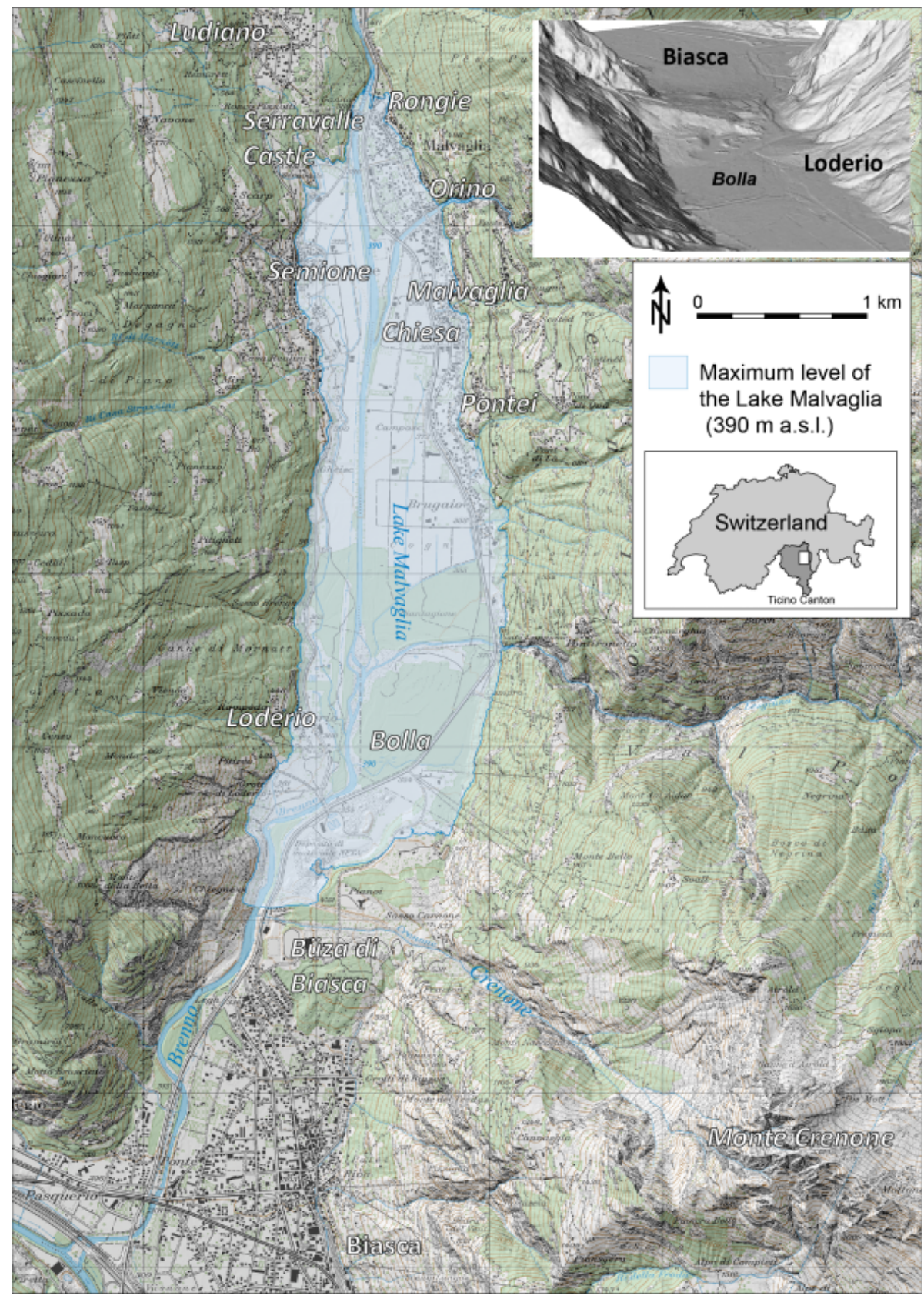

Figure 1. The lower part of the Blenio Valley before the Buzza di Biasca of 20 May 1515, with the maximum extent of Lake Malvaglia formed behind the deposits of the MCRA of 30 September 1513. In the box at top right is the view from the north of the MCRA deposits as it appears today. Cartographic basis: National Map of Switzerland 1:25000, () Swiss Federal Office of Topography swisstopo.

most $2 \mathrm{~km}^{2}$ and presenting a $300 \mathrm{~m}$ thick deposit. Several descriptions, reported and translated from German, French and English to Italian by Rossetti and Rossetti-Wiget (2013), allowed the quantification of the accumulation volume and the triggering mechanism. Concerning the volume, estimations carried out between the end of the 19th century and the first half of the 20th century range from $12-13 \mathrm{hm}^{3}$ (End, 19221923) to $15-20 \mathrm{hm}^{3}$ (Montandon, 1933) and up to $150 \mathrm{hm}^{3}$ (Heim, 1932). In recent times, new estimations range from
$15-20 \mathrm{hm}^{3}$ (Eisbacher and Clague, 1984) to $130 \mathrm{hm}^{3}$ (Rossetti and Rossetti-Wiget, 2013) and up to as much as $500 \mathrm{hm}^{3}$ (Cotti et al., 1990). For the larger estimations, it is not easy to establish whether this volume corresponds exclusively to the collapse of 1513 or whether it integrates the volume of all the events that took place in the previous centuries. Several authors propose a debris accumulation in several stages, with the collapse of 1513 being only one of the last events (e.g. Lautensach, 1910; End, 1922-1923; Montandon, 1933; Ros- 
setti and Rossetti-Wiget, 2013). For these authors, $40 \mathrm{hm}^{3}$ can be attributed to the so-called "Montegnano" cone, which accumulated before 1513. The volume of the 1513 rock avalanche, including subsequent smaller events, would therefore be approximately $90 \mathrm{hm}^{3}$.

The structure of the deposits composed of several overlapped cones was clearly recognized and described thanks to the boreholes drilled in the deposits for characterizing materials in view of the construction of the A2 (E35) national highway (Hantke, 1983; Scapozza et al., 2015; De Antoni et al., 2016), serving in the northern part of the MCRA deposit as storage of the material excavated from the Gotthard Base Tunnel of the NRLA. A new detailed description and interpretation of these borehole logs is discussed in Sect. 4.2. These stratigraphical considerations are supported by the recent documentation of a historical observation tower built in the 13th century (De Antoni et al., 2016): this tower, known as Torre di Granono, was located in Loderio (Figs. 1 and 2), and its use allowed for alerting the inhabitants of Montegnano, a hamlet of Biasca that was entirely covered by the MCRA, and all inhabitants survived the event. The few historical documents related to the MCRA (mostly written in Latin, collected and discussed by De Antoni et al., 2016) tell us about the event that (1) the MCRA fell in non-rainy weather ("fiut maxxima ruina lapidarum tempore non pluvioso"; document by notary Nicolino Rusca of Bellinzona, 1513; Brentani, 1937; De Antoni et al., 2016) and (2) the frightening sudden collapse of the Monte Crenone poured dense dust for $2 \mathrm{~h}$, reaching Locarno ("horridam ruinam montis de Carnonelpulvere per 2 horas densissimo Locarnum usque effuso"; document by Cavalier Giovanni Battista Pellanda, Biasca, 1541-Biasca, 9th March 1615; Pellanda, 1991); Locarno is located $37 \mathrm{~km}$ from Biasca.

\section{Material and methods}

\subsection{Digital mapping}

Digital mapping was based on both 2-D and 3-D Earth observation, as well as on direct in situ field mapping. The 2-D Earth observation was based on the joint analysis of three base images (for details, see Ambrosi and Scapozza, 2015): (1) hillshade generated for various exposition-angles from the swissALTI3D DEM, which has a pixel resolution of $2.0 \mathrm{~m}$ and an accuracy of $\pm 50 \mathrm{~cm}$ below $2000 \mathrm{~m}$ a.s.l. and $\pm 100-300 \mathrm{~cm}$ above $2000 \mathrm{~m}$ a.s.l. (Wiederkehr and Möri, 2013); (2) orthophotograph SWISSIMAGE, with a pixel resolution from $25 \mathrm{~cm}$ (2008 to 2019) up to $10 \mathrm{~cm}$ (from 2020); (3) the digital version of the National Map 1:25000 (sheet 1273 - Biasca) and 1:10000, based on the latest version of the swisstopo topographic landscape model (TLM). All these three base images are produces by the Swiss Federal Office of Topography swisstopo. The 3-D Earth observation was based on digital linear scanned image strips (C) swisstopo), producing aerial photographs with a pixel resolution of between 25 and $50 \mathrm{~cm}$ (Ambrosi and Scapozza, 2015). The hillshade of the DEM allowed the determination of the kind of landform, even inside the forest cover, whereas the orthophotograph and the topographical map allowed the determination of the kind of deposit, in particular outside the forest cover and above the timberline. Orthophotograph interpretation is however difficult on steep slopes because of the vertical view and the shadow effect. As a consequence, 3-D digital image strips were used as a complement to 2-D Earth observation and field mapping as they are a unique method making it possible to observe the real shape of the landforms and the extent to which this shape is effectively evident, including inside the forest cover (particularly for large hillslope instabilities) and on steep slopes (Ambrosi and Scapozza, 2015). The in situ observations have been conducted in an area of about $10 \mathrm{~km}^{2}$, covering the Crenone Valley, its flanks and the area intersected by the MCRA at the bottom of the Blenio Valley. The field mapping took $5 \mathrm{~d}$ and allowed for defining the origin of the MCRA deposit and validating its extension, outlined previously in the digital observations.

The mapping was performed according to the legend for the Geological Atlas of Switzerland 1:25000 (OFEG, 2003; Wiederkehr and Möri, 2013; Ambrosi and Scapozza, 2015).

\subsection{Historical mapping}

Geographical information systems (GISs) highly facilitate the integration of historic landscape patterns in actual topographical maps (e.g. Kienast, 1993; Stäuble et al., 2008; Scapozza, 2013). The reconstruction of the MCRA accumulation before its exploitation in the 20th century was based on the georeferentiation of the oldest detailed topographical representation of the rock avalanche accumulation: the original relief (Originalaufnahme) for the Dufour Map, drawn by Andreas Kündig and Benjamin Müller in 1854 (Fig. 2). Possible distortions related to the manual cartography performed in the middle of the 19th century were verified and corrected thanks to the first edition of the Siegfried Map (Kündig and Müller, 1881). The $30 \mathrm{~m}$ contour lines vectorized from these two historical maps were transformed into sequences of points of equivalent altitude. In the area where the topography was modified after the middle of the 19th century, these points replaced the corresponding points generated from the swissALTI3D DEM. The resulting set of points was newly interpolated for generating a DEM with the topography of the second half of 19th century in correspondence to the MCRA accumulation, which can be considered the most detailed information about the situation after the collapse of 1515 .

\subsection{Rock avalanche numerical modelling}

The numerical analysis of the MCRA focuses on the runout representation and does not concern the rock slope stability analysis prior to the failure, since the latter does not 


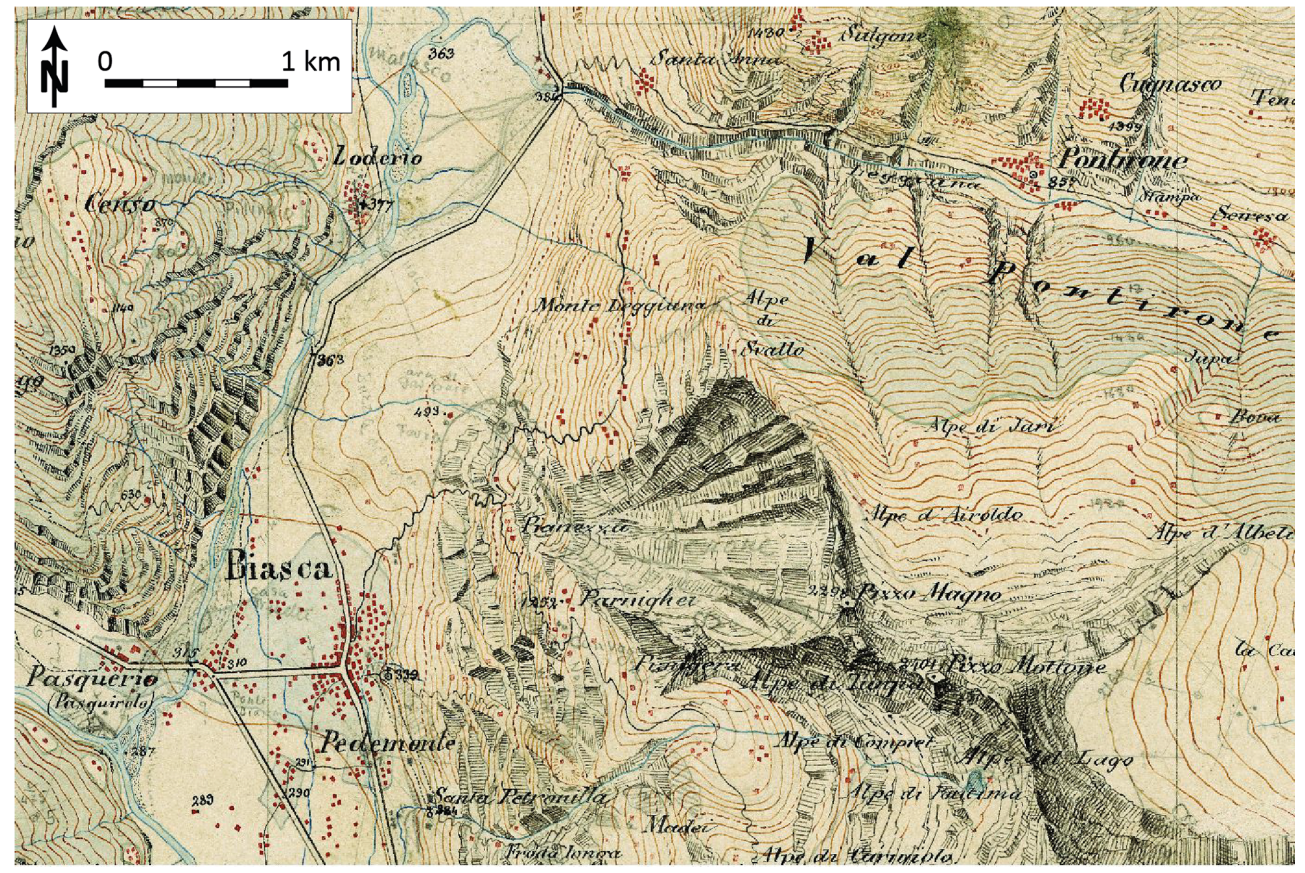

Figure 2. The first modern topographical representation of the MCRA, falling from the west side of the Pizzo Magno (alternatively called Pizzo Magn)); the accumulation is visible on the valley floor between Biasca and Loderio. Extract from the original relief for the Dufour Map (Kündig and Müller, 1854), drawn by Andreas Kündig and Benjamin Müller in 1854. (C) Swiss Federal Office of Topography swisstopo. A comparison with the actual topography is possible by observing Fig. 1.

determine a highly relevant element for the flow dynamics and deposition. The runout analysis has been performed using the 2-D numerical simulation software RAMMS (Rapid Mass Movement Simulation) DEBRISFLOW module, developed by the WSL Institute for Snow and Avalanche Research SLF (Christen et al., 2012) and obtainable on request via the RAMMS website (RAMMS rapid mass movements website, 2019). This software has been chosen because of its application of modelling rock avalanches to three cases of historical rockslides in the Canton of Ticino (Steinemann, 2012a, b, c). RAMMS utilizes the Voellmy frictional law, which applies two friction parameters to represent the frictional resistance (Pa) (see Salm, 1993; Salm et al., 1990): the dry Coulombtype friction (coefficient $\mu$ ) and the viscous turbulent friction (coefficient $\xi$ ), responsible for the behaviour of the flow. $\mu$ dominates when the flow is close to stopping, whereas $\xi$ dominates when the flow is running rapidly. The frictional resistance equation also considers the density $\rho$; the gravitational acceleration $g$; the slope angle $\varphi$; the flow height $h$; and the vector $u$, consisting of the flow velocity in the $x$ and $y$ directions (Bartelt et al., 2017). Besides the calibration of $\mu$ and $\xi$, other parameters have to be empirically defined to run the simulation: the stop parameter based on the momentum $p$ (SI unit $\mathrm{kg} \mathrm{m} \mathrm{s}^{-1}$ ) is the product of an object mass and velocity and controls the numerical diffusion. The RAMMS user manual suggests values of between $1 \%-10 \%$, but the most suitable value has to be determined for each test case. $\lambda$ is the Earth pressure coefficient that modifies the longitudinal pressure gradients driving the flow. RAMMS user manual recommends not to change the default value because the set value of 1.0 disables the effect of $\lambda$.

In the Release Tab, RAMMS requests if the simulation concern an unchannelized or channelized debris flow. The former implies the Block Release sub-tab choice, where a release area defines the mobilized volume with a given initial depth. The latter requires the Hydrograph sub-tab, which requests to determine the discharge hydrograph and is not recommended for this study because it requires a deep knowledge of flow dynamics in terms of the debris flow rate $\left(\mathrm{m}^{2} \mathrm{~s}^{-1}\right)$ in a defined section. A final tab relative to the erosion predicts the depth of the erosion of the sediment and so the potential entrainment.

Before calibrating the cited parameters, the model needs as input data a DEM of the pre-failure surface and the mobilized mass volume. The latter was obtained directly by numerical modelling on the basis of the deposition results. The release volume does not represent the actual geometry of the collapsed body. Instead, it is defined by a fictitious release area combined with a release depth inside the Release Tab. 


\section{Results}

\subsection{Digital mapping}

The mapping at a scale of $1: 10000$ highlights the deposits' nature, recognized through the field surveys and the geomorphological elements already mapped in the SUPSI landslide inventory map of the Canton of Ticino.

The trace of the MCRA on the bottom of the lower Blenio Valley consists of impressive, well-recognizable debris accumulation at the mouth of the Crenone Valley (see Sect. 2.1). In particular, along the right side of the Crenone stream, from the MCRA debris cone summit (Pt. 1 in Fig. 3) toward the west, a roughly $700 \mathrm{~m}$ long and 10-30 m high morphological crest dominates the landscape (Fig. 4c). This crest is characterized by sub-angulated grain-supported boulders of augen gneiss and leucocratic gneiss of the Simano nappe, exceeding $1 \mathrm{~m}$ in diameter (Fig. 4e). Again on the Crenone stream's right side, the deposit persists further east inside the Crenone Valley and traces the altitude limit of the MCRA flow (Pt. 2 in Fig. 3). At the opposite side of the Crenone stream (Pt. 3 in Fig. 3), the MCRA deposit appears to be more distributed over the slope (Fig. 4f) and maintains the size and lithology but shows a higher percentage of matrix. Outward from the cone, both the deposits continue with a smaller slope gradient.

Part of the MCRA deposit is also recognizable along the river Brenno's right side (Chiegnezz locality, Pt. 4 in Fig. 3; Fig. 4d), where it reaches an altitude of $420 \mathrm{~m}$ a.s.l. The material is constituted by a massive diamicton, matrix supported (lithofacies code Dmm), composed of sub-angulated clasts of augen gneiss and leucocratic gneiss within a very well graded silty sand (20\% fine) of light beige colour (Prandi, 2018). In this area, the erosional action of the Buzza is well visible on a gradient change, from the original deposit altitude (420 $\mathrm{m}$ a.s.1.) to the river Brenno altitude ( $350 \mathrm{~m}$ a.s.1.).

In the northernmost area (Pt. 5 in Fig. 3), the MCRA deposit is deeply reshaped by the succession of works, starting with the excavation of inert material used mainly for the construction of the national highway and, in earlier times, the deposition of materials coming from the NRLA.

Along the Crenone riverbed, the deposit derives from the torrential and debris flow transport subsequent to the MCRA.

\subsection{The MCRA pre-failure morphology reconstruction}

The attempt to recreate the MCRA pre-failure morphology of the Blenio Valley (pre-failure surface in the following sections) is the major challenge of this study. As no maps are available prior to the mid-19th century (see Sect. 3.2), information about the deposit thickness and extension derives from the boreholes completed during the geotechnical studies performed for the construction of the national highway A2 (E35) and from the remaining in situ MCRA deposits.
Borehole data were extracted from the GESPOS (Gestione Sondaggi, Pozzi e Sorgenti) database (managed by the SUPSI Institute of Earth Sciences) containing drilling data, well logs and springs in the Canton of Ticino territory. From the five boreholes completed in 1974, the three boreholes identified through GESPOS, IDs 701.27, 701.31 and 701.30, are located in the northernmost deposit portion and allow the quantification of the deposit thickness at their sites (Fig. 3). Because the boreholes were drilled in 1974, the shown thicknesses are reduced compared to the original MCRA deposit, which was not eroded by the Buzza di Biasca of 1515. Borehole 701.27 shows $24.2 \mathrm{~m}$ of coarse deposits that could be attributed to the MCRA on the basis of the grain size and on the depositional facies (Fig. 5a). Borehole 701.30 presents $13.5 \mathrm{~m}$ of deposits attributed to the MCRA (Hantke, 1983) (Fig. 5b). According to the comparison with the historical topographical maps of the second half of the 19th century (Fig. 2), the extra deposit thickness in borehole 701.30 could reach an altitude of about $420 \mathrm{~m}$ a.s.l.; the total deposit thickness associated with the MCRA could be estimated to be about $30 \mathrm{~m}$ (Fig. 5). Borehole 701.31 drilled in the most distal part of the cone shows an erosion of the MCRA accumulation of about $30 \mathrm{~m}$, considering the original deposit altitude of $390 \mathrm{~m}$ a.s.1. (Fig. 5c). Considering the $13.85 \mathrm{~m}$ of rock avalanche deposit in this location, the original deposit thickness just after the MCRA falling was probably at least $40 \mathrm{~m}$.

The incised MCRA deposit along the river Brenno's right side is the only information on the deposit thickness in the western part of the accumulation area (Fig. 4d) and provides a key element to understanding the MCRA flow. Indeed, its extension and position force us to think of strong downstream path curvature. Flow propagation following the valley axis would provide too much deposition upstream, not supported by the current geomorphological evidence. According to the field and borehole evidence, the best prefailure MCRA Blenio Valley surface was selected by performing several numerical models and evaluating which prefailure surface could better host the failure mass. The final pre-failure surface shown in Fig. 6 represents a debris cone that is clearly smaller than the current one. The central cone section shows a $900 \mathrm{~m}$ long, $30 \mathrm{~m}$ high morphological crest covering the easternmost part of the current crest described in Sect. 4.1. This geomorphological element channelled the MCRA flow southward in agreement with the field observations and suggests a strong erosional activity prior to the MCRA. Finally, the pre-failure contour surface on the river Brenno's right side removes the MCRA deposit and has been tracked considering the steep slope morphology. 


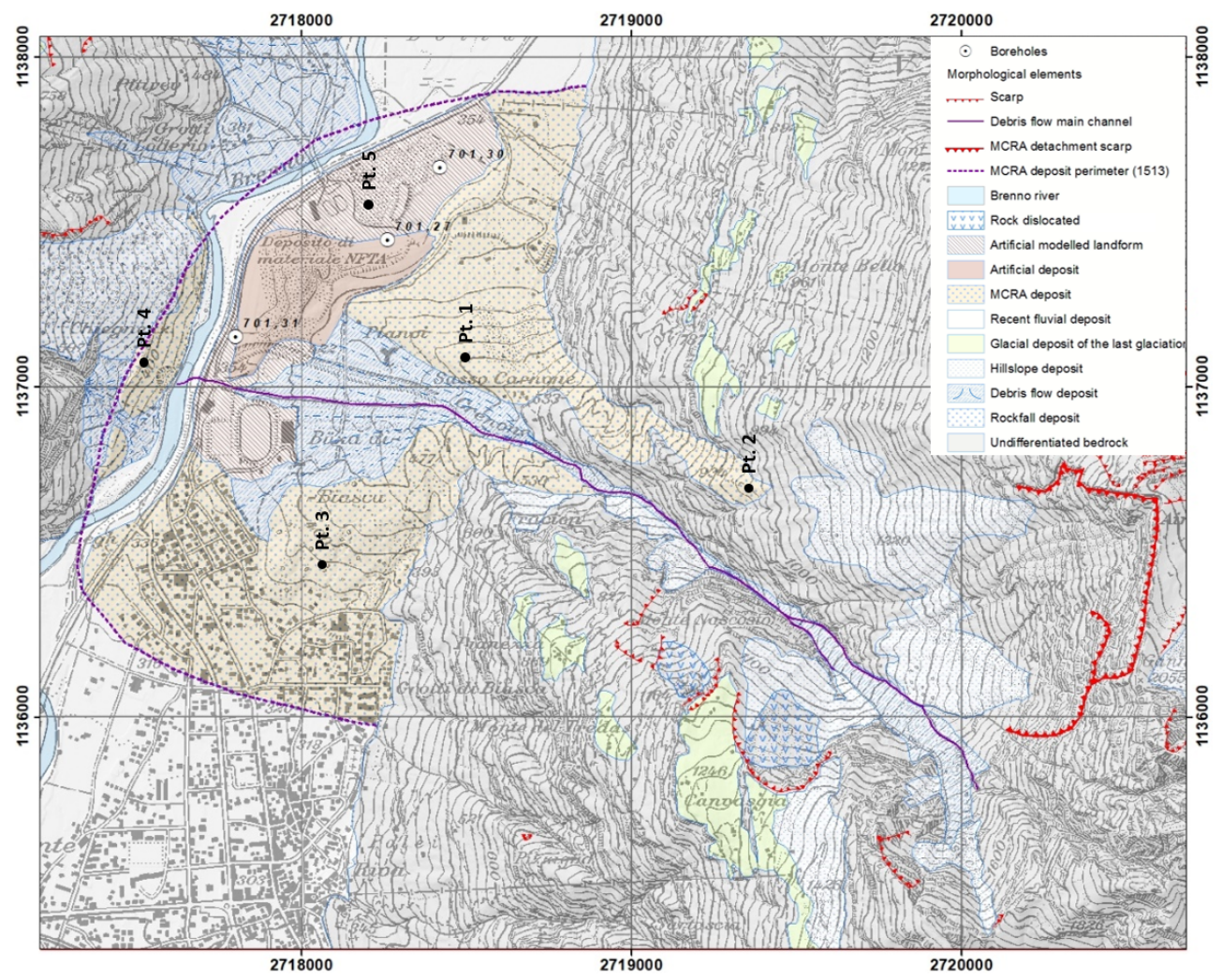

Figure 3. Geomorphological map of the lower part of the Blenio Valley, reporting the morphostructures and deposits associated with the MCRA of 1515 and following events. Cartographic basis: National Map of Switzerland 1:25000, (C) Swiss Federal Office of Topography swisstopo.

\subsection{Numerical modelling of the MCRA}

\subsubsection{Model setup}

The numerical modelling of the MCRA has the aim of identifying a best-fit simulation in terms of runout propagation, distribution, deposit thickness and flow velocity plausibility. The attempt to reproduce the MCRA through numerical modelling meets strong criticism, and unavoidable simplifications have to be adopted. The first criticism, as mentioned in Sect. 4.2, derives from the lack of knowledge of the exact morphology preceding the 1513 event. The suggested shape and depth of the pre-failure surface under the MCRA deposit is not confirmed by any data in the central and southern part of the cone. Consequently, the numerical modelling parameters assume a considerable margin of variability. Furthermore, no data on the event dynamics and timing exist.

With respect to the pre-failure surface, a $10 \mathrm{~m}$ DEM resolution has been considered suitable for the model's needs to run the simulation. Considering the uncertainty of the reconstructed surface, a higher resolution would not bring more accurate results regarding the phenomenon veracity. For the flow density, the value of $2500 \mathrm{~kg} \mathrm{~m}^{-3}$ is considered a realistic mean value for hard crystalline rocks, and it has been chosen in all the case studies analysed with RAMMS::DEBRISFLOW in the Canton of Ticino (Steinemann, 2012a, b, c). Concerning the values for the $\mu$ and $\xi$ parameters, detailed back analysis was carried out to find the best simulation to fit the post-event morphology discussed in Sect. 4.1. The frictional parameters established were $\mu=0.40$ and $\xi=600$, values within the range suggested in the RAMMS manual. The extracts of the RAMMS::DEBRISFLOW simulation for the MCRA, varying the calibration of $p, \xi$ and $\mu$, are shown in Fig. 7. The high value of the viscous turbulent friction (coefficient $\xi$ ) highlights the turbulent flow motion, whereas the low value of the Coulomb-type friction (coefficient $\mu$ ) denotes high resistance of the solid phase expressed inside the simulation as a high deposition at the mouth of the Crenone Valley.

\subsubsection{Flow dynamics}

The numerical simulation represents the MCRA as a single event. The difference in the altitude of the path associated with a narrow valley on a reduced path acts on the strong energy of the phenomenon. The high turbulence shown in the numerical modelling is confirmed through the relatively small size of the boulders (metric diameter) in relation to the volume of the deposit (Fig. 5e, f). 

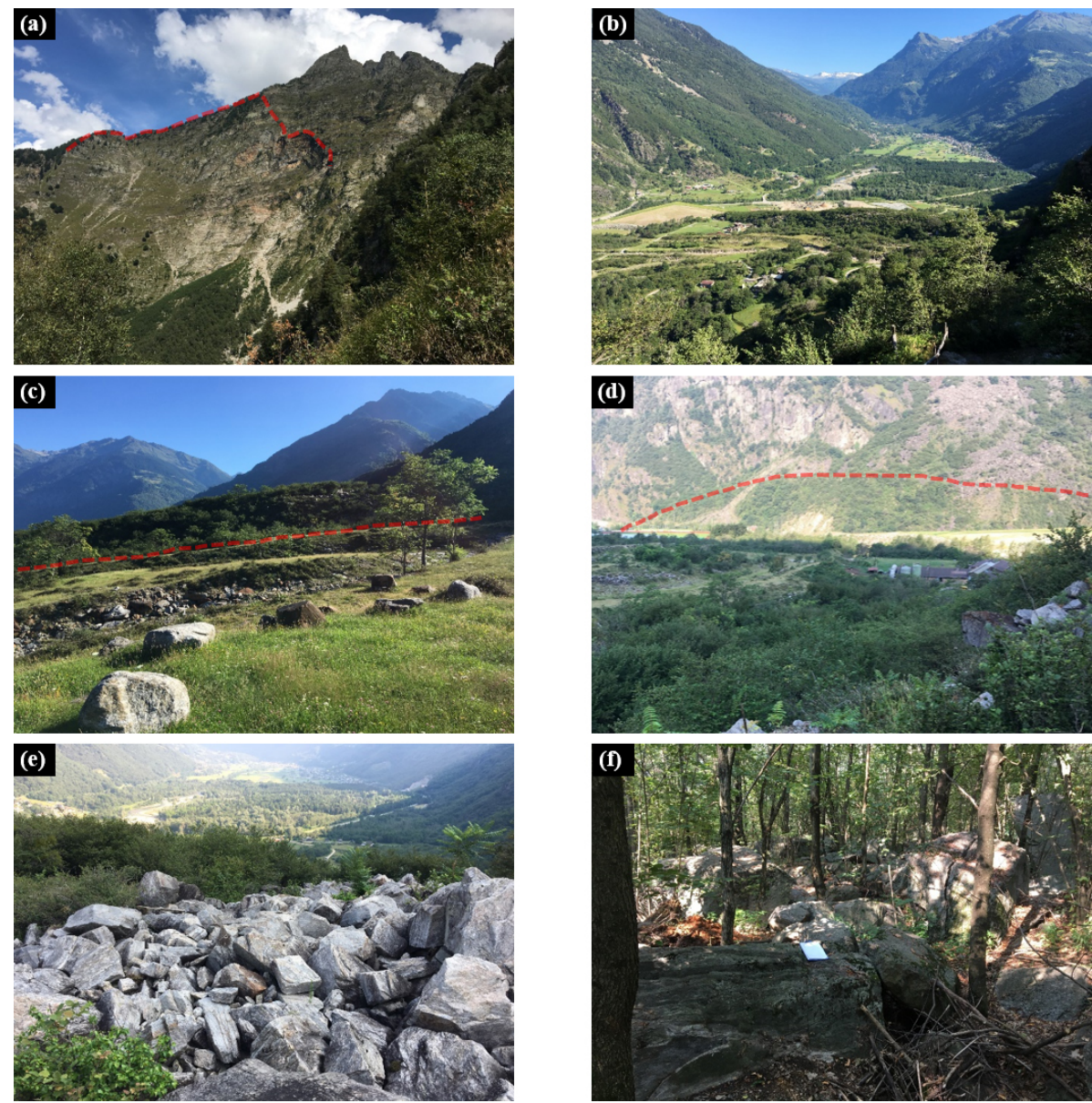

Figure 4. Field photographs of the current situation of MCRA morphostructures and deposits. (a) Monte Crenone west side. The crest oriented north-south is about $1.4 \mathrm{~km}$ long. The detachment niche is outlined with a red line. (b) MCRA deposit and floodplain between Loderio and Malvaglia, $1 \mathrm{~km}$ wide on average. (c) Morphological $20 \mathrm{~m}$ high crest along the Crenone stream's right side. The dashed line represents the crest lower limit. (d) MCRA deposit along the Blenio Valley's right side, extended for about $1 \mathrm{~km}$; the dashed line depicts the upper limit. (e) MCRA deposit on the morphological crest reported in (c); the boulders have an average diameter of $1 \mathrm{~m}$; (f) MCRA deposit on the left side of the Crenone stream. The scale is represented by the white A4 paper in the middle.

The flow height shown in the numerical modelling finds agreement with the NNE-SSW accumulation on the Crenone Valley's right side (Fig. 8c), passing by the deposit (Pt. 2 in Fig. 3), and the flow motion $110 \mathrm{~s}$ after the initial collapse is plausible.

\subsubsection{Deposit distribution}

The final model attributes a calibrated deposit volume of $85.5 \mathrm{hm}^{3}$ to the MCRA, which is coherent with the values cited in the literature (see Sect. 2.2). The MCRA deposit resulting from the numerical modelling simulation presents a good match with the post-event deposit morphology reproduced in the depositional area (Fig. 9). The deposit thickness along the current river Brenno path reaches an elevation of up to $390 \mathrm{~m}$ a.s.l., in agreement with the maximum level of Lake Malvaglia. On the northern part of the MCRA cone, the produced volume agrees with the historical topographical maps and the $80 \mathrm{~m}$ of thickness represented by the yellow lobe in Fig. $8 \mathrm{f}$ is the result of flow channelling (see Pt. 2 in Fig. 3). On the southern part, even if the current deposit has been locally eroded, the numerical model results seem to fill the exported volumes and so well reproduce the original MCRA deposit.

\section{Discussion}

\subsection{Numerical modelling of historical rockslides}

Table 1 shows a comparison among the RAMMS::DEBRISFLOW modelling calibrations performed on the MCRA and three other case studies on rockslides in the Canton of Ticino. The models proposed by Steinemann (2012a, b, c) were performed to find optimal input parameters to use RAMMS for hazard prediction for an unstable slope in the Maggia Valley. A clear difference 


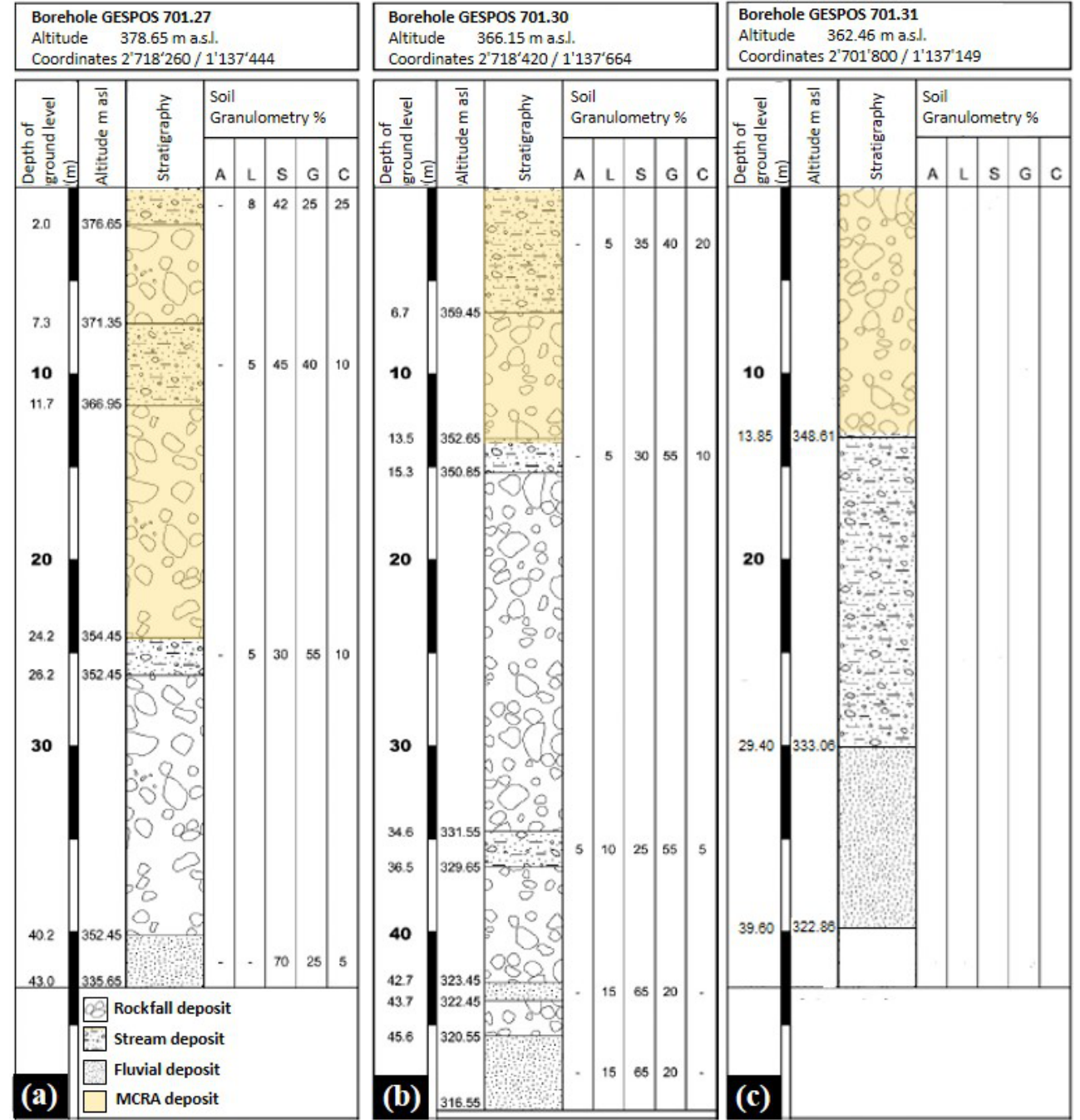

Figure 5. Stratigraphy of GESPOS boreholes 701.27, 701.30 and 701.31 drilled on the Monte Crenone debris cone.

between the MCRA modelling parameters and the other case studies is present. Utilizing the Preonzo rockslide dataset on the MCRA case, the model shows a runout that is twice more extended than the real case and a failure time of $32 \mathrm{~min}$. The difference between the RAMMS models parametrization proposed by Steinemann (2012b) in his case studies and the MCRA model could be related to the huge difference in the volume magnitude and the path. Indeed, if for the Sasso Rosso, Preonzo and Cè rockslides, the accumulation is not constrained by the topography, the path is tightened at the mouth of the Crenone Valley for the MCRA.

This particular morphological conformation associated with the large volumes involved gives the movement a very particular kinematics with associated high turbulence.

\subsection{Consequences of the MCRA}

\subsubsection{Lake Malvaglia growing and Buzza di Biasca triggering}

The reconstruction of the MCRA runout model allowed us to confirm the historical data about this event, in particular the damming of the valley floor up to an elevation of $390 \mathrm{~m}$ a.s.l. and the subsequent creation of a lake which reached a maximum extension of $4.5 \mathrm{~km}$ and $130 \mathrm{hm}^{3}$ (see Scapozza et al., 2015; De Antoni et al., 2016). The silty sand matrix of the Dmm of the distal part of the MCRA accumulation (see Sect. 4.1), which was generated by the high interaction between the clasts during the rock avalanche falling, allowed the accumulation to be partially impermeable to the water passage. Considering a mean runoff of the river Brenno of $8-18 \mathrm{~m}^{3} \mathrm{~s}^{-1}$ (Scapozza et al., 2015), the theoretical filling time of the $130 \mathrm{hm}^{3}$ lake would be between 3 and 6 months. The growth of the lake was probably slowed down by the 


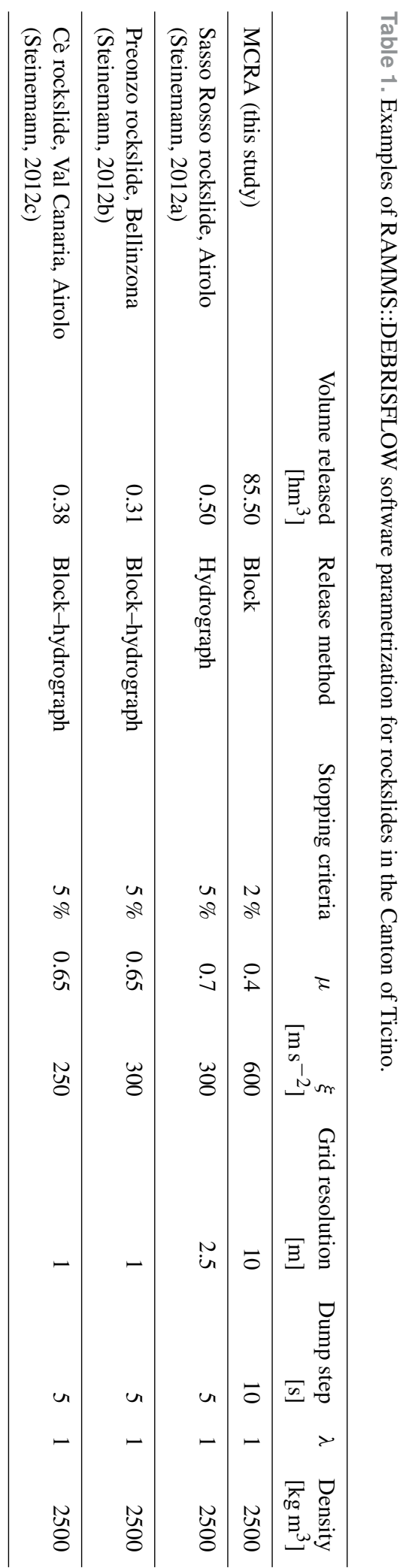

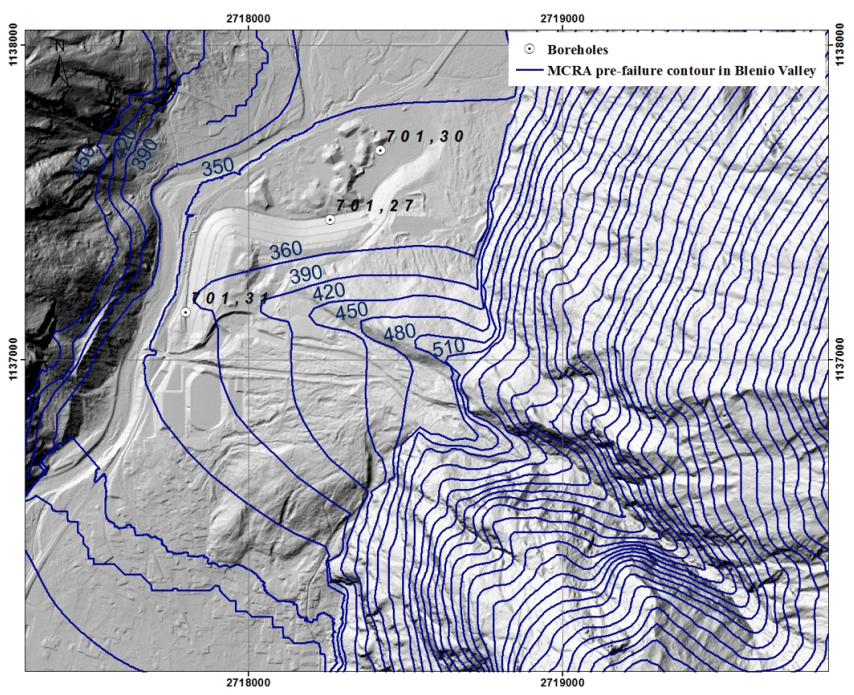

Figure 6. Contour lines of the lower part of the Blenio Valley as reconstructed for the pre-MCRA falling. Cartographic basis: hillshade derived from the swissALTI3D digital elevation model, (c) Swiss Federal Office of Topography swisstopo.

higher initial porosity of the accumulation, which decreased in the following 2 years as a consequence of the fine lacustrine sedimentation filling the pores and decreasing the effective porosity, making the dam increasingly impermeable. The time elapsed between the MCRA and the breaking of the natural dam, which generated the Buzza di Biasca, is probably equivalent to the time the lake took to gradually reach the maximum level at $390 \mathrm{~m}$ a.s.1.

The runout model of the Buzza di Biasca considers an occurrence of the breakage shortly after the lake overflow, with subsequent triggering of a sudden chain reaction (Scapozza et al., 2015; De Antoni et al., 2016). The Buzza di Biasca simulation indicates a flood peak at the breach of about $50000-60000 \mathrm{~m}^{3} \mathrm{~s}^{-1}$, decreasing progressively toward Lake Maggiore; the peak reached about $15000 \mathrm{~m}^{3} \mathrm{~s}^{-1}$ in Bellinzona (where the flood wave arrived less than $1 \mathrm{~h}$ after the dam collapsing, with an average wave front velocity of $6-8 \mathrm{~m} \mathrm{~s}^{-1}$ ) and about $12000 \mathrm{~m}^{3} \mathrm{~s}^{-1}$ in Magadino, reaching Lake Maggiore about $2.5 \mathrm{~h}$ after the collapse of the dam (with an average wave front velocity of 3-4 $\mathrm{m} \mathrm{s}^{-1}$ between Bellinzona and Lake Maggiore). As a comparison, the maximum discharge reached in Magadino was about 5 times higher the maximum estimated runoff for the 1868 flood, which was $2500 \mathrm{~m}^{3} \mathrm{~s}^{-1}$ (Piffaretti and Luchessa, 2011). Depth peaks of around $10-12 \mathrm{~m}$ were simulated along the Riviera valley, gradually decreasing as the flood descended southward, reaching approximately $5 \mathrm{~m}$ on the Piano di Magadino. The flood wave caused a rise of about $0.60 \mathrm{~m}$ in Lake Maggiore about $5 \mathrm{~h}$ after the formation of the breach (Scapozza et al., 2015; De Antoni et al., 2016). 

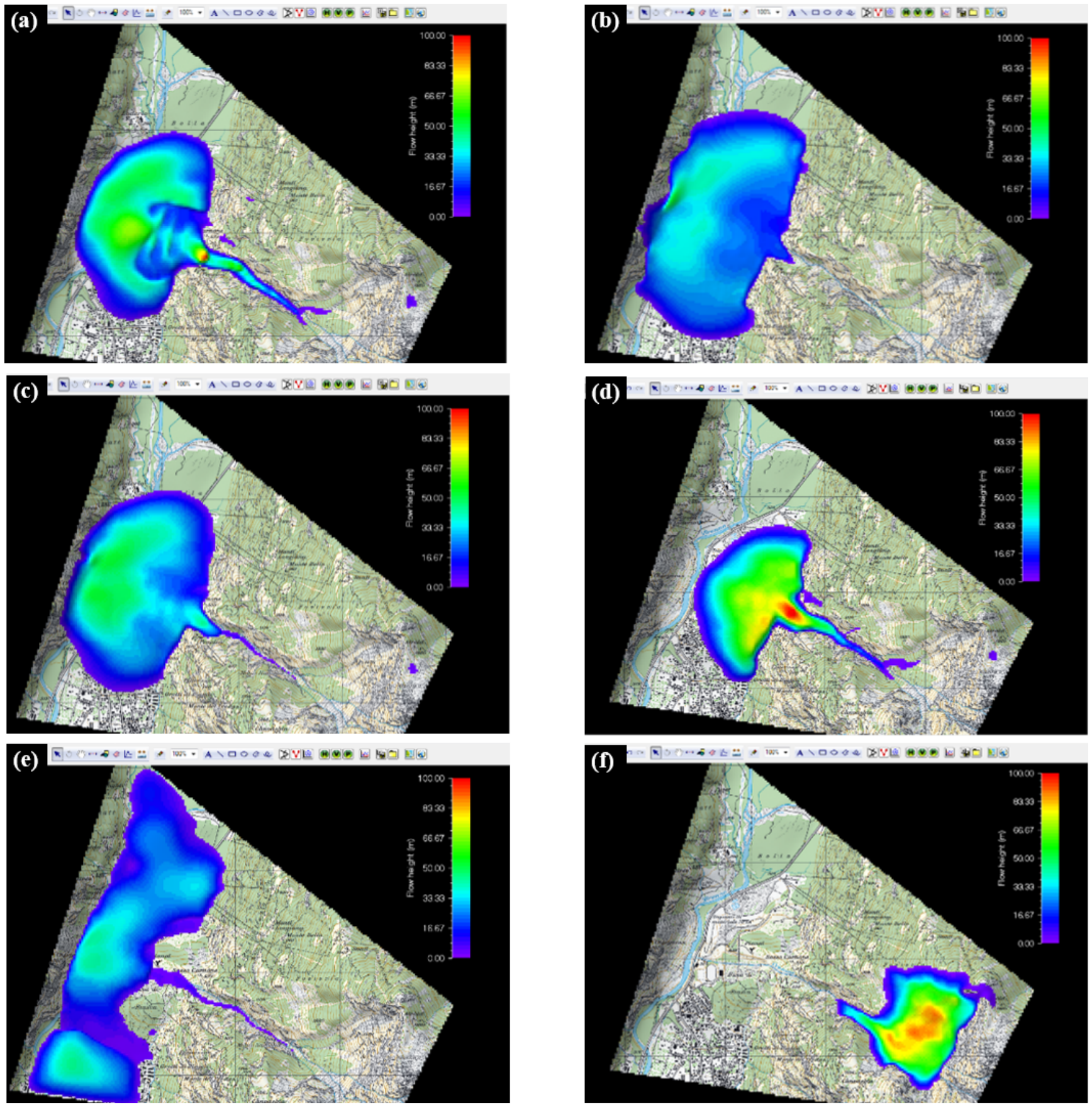

Figure 7. Several attempts to model the MCRA by varying the $P, \xi$ and $\mu$ parameters: (a) $P=10 \%, \xi=600, \mu=0.35$; (b) $P=1 \%$, $\xi=600, \mu=0.35$; (c) $P=2 \%, \xi=1000, \mu=0.35$; (d) $P=2 \%, \xi=100, \mu=0.35$; (e) $P=2 \%, \xi=600, \mu=0.10$; and (f) $P=2 \%$, $\xi=600, \mu=1$. Values in italics are the variate parameters for every scenario. Cartographic basis: National Map of Switzerland 1:25 000, (C) Swiss Federal office for topography swisstopo.

\subsubsection{Sediment flux generated from the Buzza di Biasca}

If the historical and territorial consequences of the extreme flood generated by the collapse of the dam constituted by the MCRA accumulation are well known (e.g. Pometta, 1928; Galli, 1937; Solari, 1982; and Colombo, 1999, and their sum- mary and critical analysis in Scapozza et al., 2015, and De Antoni et al., 2016), less information is available concerning the sedimentary and morphological impact of this event. Recent investigations carried out into the fluvial morphology of the river Ticino floodplain and delta between Bellinzona and Lake Maggiore indicate, as a consequence of the Buzza 

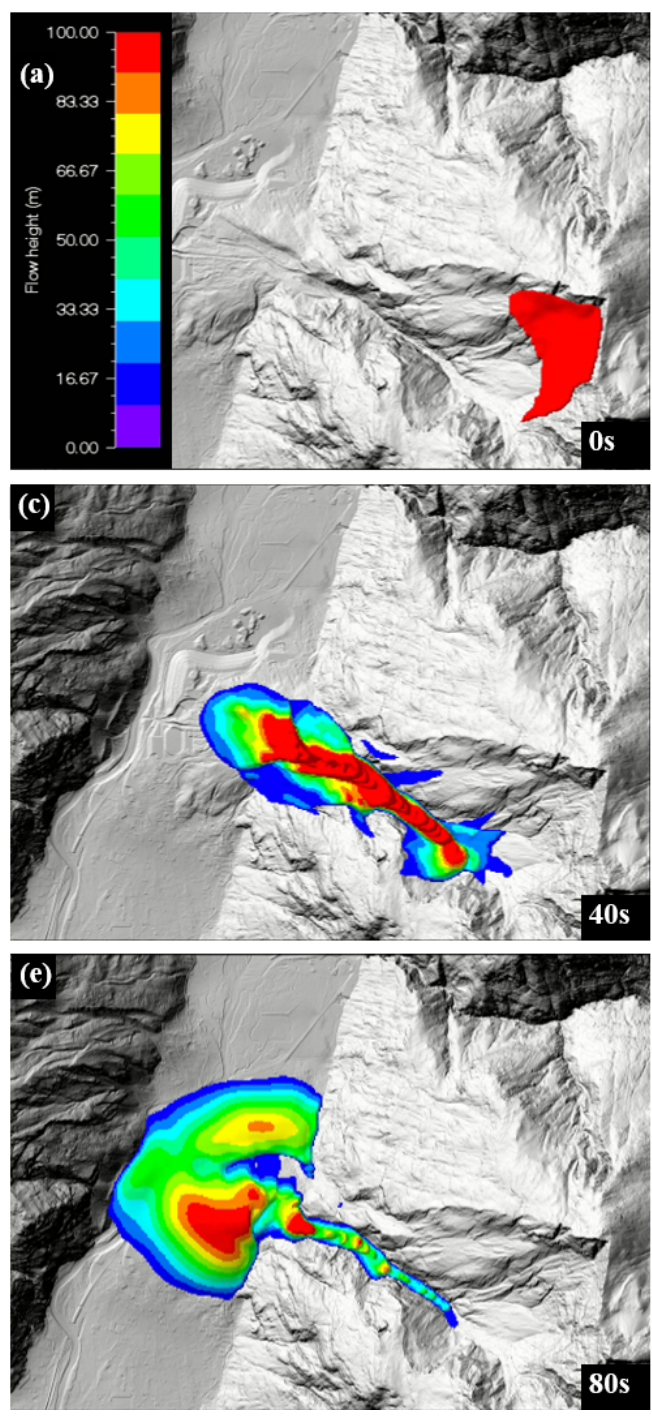
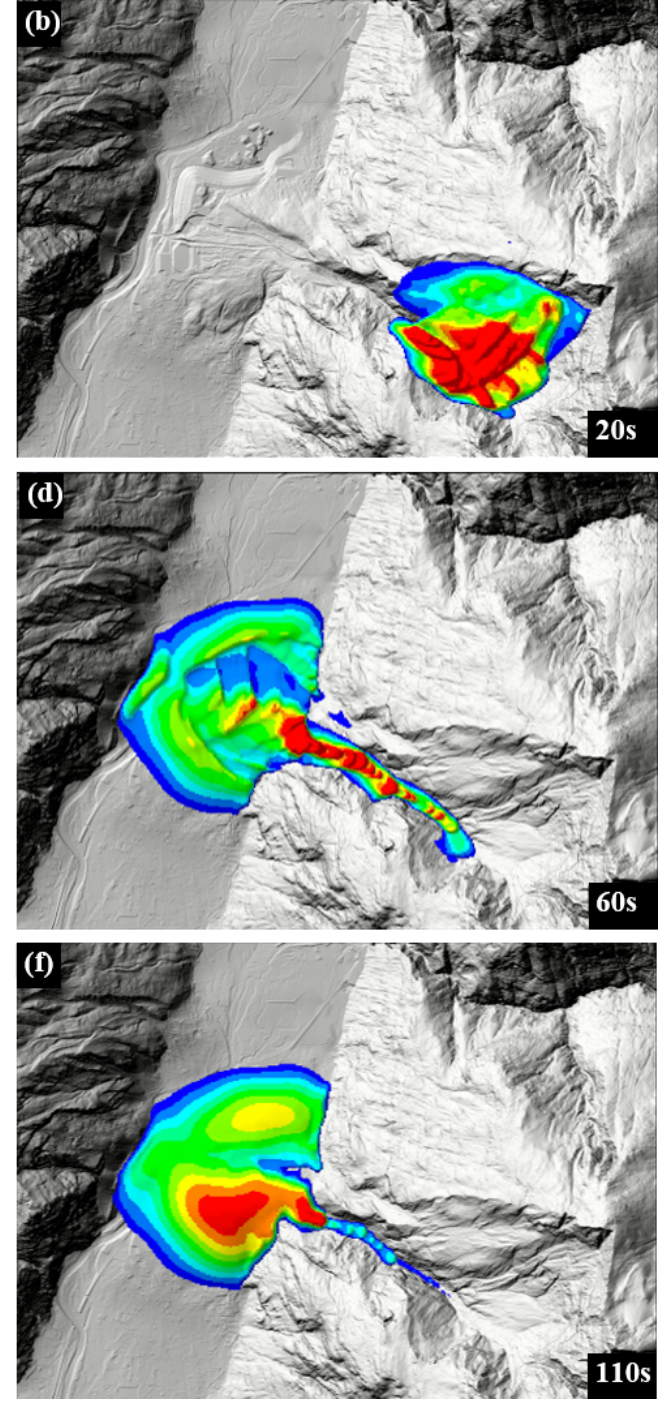

Figure 8. Results of the numerical modelling of the MCRA, with the representation of flow heights every $20 \mathrm{~s}$ ( $30 \mathrm{~s}$ for the last image). Cartographic basis: hillshade derived from the swissALTI3D digital elevation model, @ Swiss Federal Office of Topography swisstopo.

di Biasca of 1515, the following: (1) the migration of the Ticino river mouth from the south to the north, (2) the rapid progradation of the Ticino river delta and (3) the fluvial metamorphosis of the river Ticino from a meandering to a braided morphology (for a detailed analysis of these three main points, see Scapozza, 2013; Scapozza and Oppizzi, 2013; Scapozza and Ambrosi, 2021).

The fluvial metamorphosis probably also concerned the floodplain of the river Ticino between Biasca and Bellinzona, as seems to be indicated by a recently rediscovered topographic map of the valley floor between Biasca and Lodrino in 1785, conserved in the historical archive of the Biasca municipality (Fig. 10a). The river morphology is braided, even if the probable original meandering morphology is still well recognizable, with the gravel bars linked with the meanders' migration (Fig. 10b). The most recent channels mainly affect the alluvial forest, indicating that their origin must have been relatively recent (perhaps on the order of several centuries). West of Biasca, two palaeo-channels of the river Ticino are clearly recognizable and are marked on the maps as "Ramo mairano" (from the locality of Mairano, near Iragna) and as "Letto vecchio" (literally "old riverbed"). Between Pasquerio and Mairano, the river Ticino did not flow completely on the right side of the valley floor as it did after its correction at the beginning of 20th century but in a more central position (Fig. 10c).

Chronostratigraphic evidence of the sedimentary effect of the Buzza di Biasca on the river Ticino floodplain is very limited. It indicates a very limited fluvial deposit input on the floodplain $\left(<1 \mathrm{~m} \mathrm{kyr}^{-1}\right)$. In the locality of Gaggiolo Lungo near Gudo, the discovery in a trench of a wood pole dating from $1840 \mathrm{CE}$ (median age of Beta-441293, Table 2), in- 
Table 2. Compilation and calibration of radiocarbon ages discussed in the text. Calibration was performed with OxCal 4.4 software, using the IntCal20 curve and with a $2 \sigma$ range (95.4\% probability). Sources are (1) Scapozza et al. (2017) and (2) Scapozza and Oppizzi (2013).

\begin{tabular}{llrrrr}
\hline Lab code & Locality & $\begin{array}{r}\text { Depth } \\
{[\mathrm{m}]}\end{array}$ & $\begin{array}{r}\text { Conventional age } \\
{\left[{ }^{14} \text { C years BP] }\right.}\end{array}$ & $\begin{array}{r}\text { Calibrated age } \\
\text { [cal BP] }\end{array}$ & $\begin{array}{r}\text { Calibrated age } \\
\text { [CE] }\end{array}$ \\
\hline Beta-441293 & Gudo, Gaggiolo Lungo (1) & 1.79 & $100 \pm 30$ & $\begin{array}{r}270-210(26.1 \%) \\
150-20(69.3 \%)\end{array}$ & $\begin{array}{r}1680-1740(26.1 \%) \\
1800-1930(69.3 \%)\end{array}$ \\
\hline Beta-443897 & & 2.26 & $580 \pm 30$ & $650-580(64.6 \%)$ & $1300-1370(64.6 \%)$ \\
& & & & $570-530(30.9 \%)$ & $1380-1420(30.9 \%)$ \\
\hline Poz-31077 & Magadino, & 5.85 & $50 \pm 30$ & $260-220(27.3 \%)$ & $1690-1730(27.3 \%)$ \\
& Castellaccio (2) & & & $140-30(68.1 \%)$ & $1810-1920(68.1 \%)$ \\
\hline Poz-31079 & & 15.00 & $1080 \pm 30$ & $1060-920(95.4 \%)$ & $890-1030(95.4 \%)$ \\
\hline Poz-31084 & & 49.70 & $1940 \pm 35$ & $1980-1740(95.4 \%)$ & $30-210(95.4 \%)$ \\
\hline
\end{tabular}

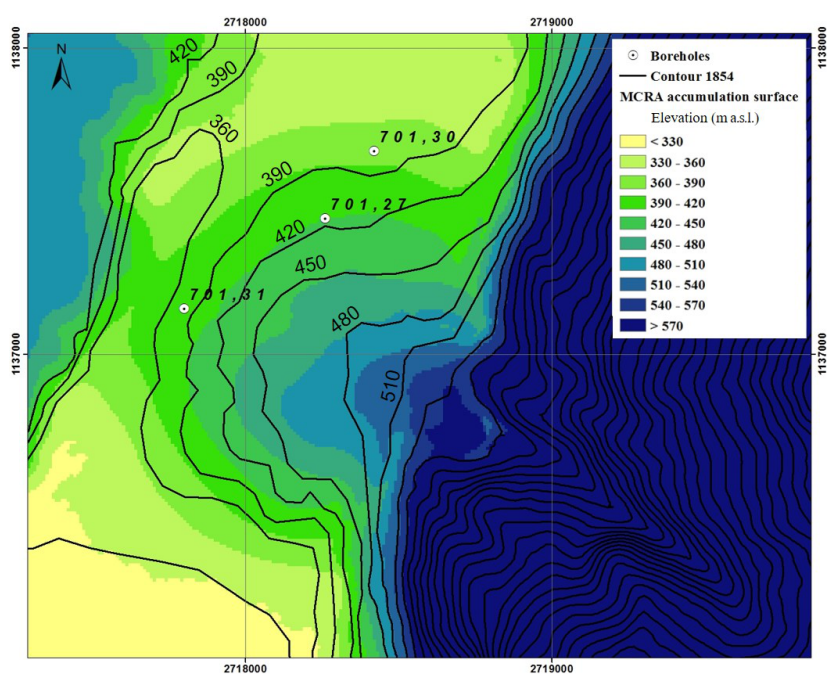

Figure 9. The MCRA accumulation surface obtained by numerical modelling added to the pre-failure DEM.

serted in organic silt deposited after 1350 CE (median age of Beta-443897, Table 2), indicates a $0.96 \mathrm{~m} \mathrm{kyr}^{-1}$ regular- and fine-grained sedimentation (Table 3), even with the occurrence of the 1515 event. Data from the Ticino river delta indicate a mean sedimentation rate of $25.20 \mathrm{~m} \mathrm{kyr}^{-1}$ between 90 and 1830 CE (median ages of Poz-31084 and Poz-3107, respectively; Table 2), composed of a very high sedimentation rate of $39.43 \mathrm{~m} \mathrm{kyr}^{-1}$ between 90 and $970 \mathrm{CE}$ (median age of Poz-31079, Table 2) and followed by a sudden decrease (Table 3): the sedimentation rate between 970 and $1830 \mathrm{CE}$, including the 1515 event, was "only" $10.64 \mathrm{~m} \mathrm{kyr}^{-1}$. The lowest sedimentations rates were assessed thanks to two archaeological excavations carried out in 1968 on sites located on the river Ticino floodplain near Bellinzona (Table 3). In Carasso, Lusanico, Early Middle Ages buildings of the period 600 $800 \mathrm{CE}$ were discovered only below $0.60 \mathrm{~m}$ of fluvial sediments, whereas in Giubiasco, High Middle Ages tombs of the 1000-1200 CE period were found below a sedimentary cover of $0.40-0.50 \mathrm{~m}$ (Donati, 1969). Only in one site was the erosive effect related to the Buzza di Biasca of 1515 clearly evidenced: a fragment of the lowest part of the defensive wall (known as the "Murata") of the medieval part of Bellinzona was discovered completely overturned during the building of the Archivio di Stato in 1993 (Donati, 1999; Scapozza et al., 2015). The erosional action at the base of the Murata was of about $1.5-2.3 \mathrm{~m}$. The subsequent fluvial deposition, probably also including sediments of the last part of Buzza di Biasca flooding, was $1.25 \mathrm{~m}$, corresponding with a mean sedimentation rate of $2.60 \mathrm{~m} \mathrm{kyr}^{-1}$ (Table 3).

\section{Conclusions}

Five main conclusions can be drawn from the observations and modelling of the MCRA event:

1. Geological observations (in particular the stratigraphy of boreholes crossing the MCRA deposit) as well as the historical sources (in particular the existence of the Granono tower) indicate a series of collapses from the Monte Crenone that began at least as early as the 13th century, leading to the main rock avalanche of 30 September 1513, with a reconstructed volume of about $85.5 \mathrm{hm}^{3}$.

2. The MCRA modelling thanks to the RAMMS::DEBRISFLOW module allowed for a precise reconstruction of the event and of the accumulation volume and geometry. It was possible in particular to determine a slight rise in the rock avalanche front on the right-hand side of the Blenio Valley, where even today there is a clear morphological trace of this event, and the damming of the valley floor up to an altitude of $390 \mathrm{~m}$ a.s.l., which corresponds with the maximum level of Lake Malvaglia just before the triggering of the Buzza di Biasca of 20 May 1515. The comparison of 

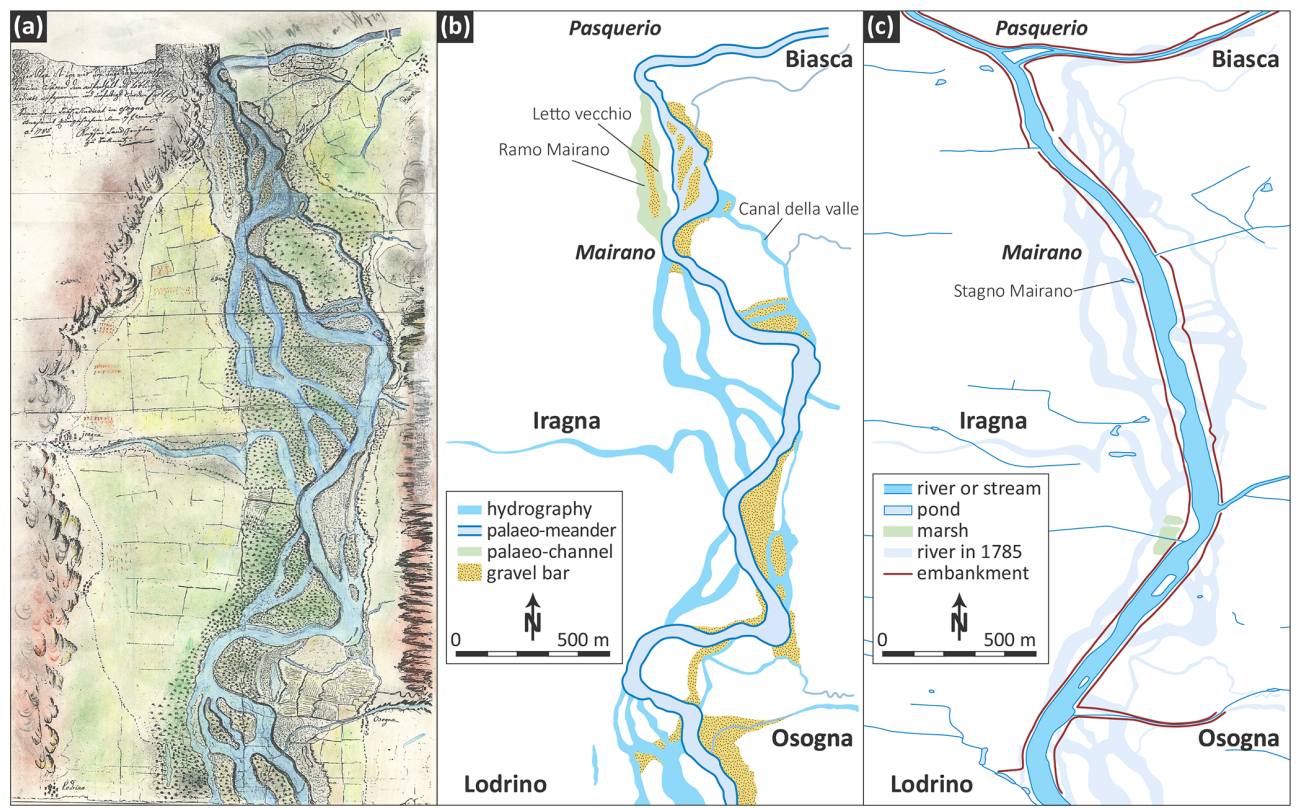

Figure 10. The Riviera valley floor between Biasca and Lodrino in 1785. (a) Colour copy of the topographical map conserved in the historical archive of the Biasca municipality; (b) interpretation of the river morphology; (c) deformed superimposition of the current river Ticino morphology, constrained by the embankments completed at the beginning of the 20th century. Cartography: Cristian Scapozza.

Table 3. Sedimentation rates on the Ticino floodplain during the period including the Buzza di Biasca event, quantified thanks to the radiocarbon dating presented in Table 2. Sources are (1) Scapozza et al. (2017), (2) Scapozza and Oppizzi (2013), (3) Donati (1969), and (4) Donati (1999).

\begin{tabular}{|c|c|c|c|c|c|c|}
\hline Locality & $\begin{array}{l}\text { Coordinates } \\
(\mathrm{CH} 1903+/ \mathrm{LV} 95)\end{array}$ & $\begin{array}{r}\text { Depth } \\
{[\mathrm{m}]}\end{array}$ & $\begin{array}{r}\text { Median age } \\
{[\text { cal BP] }}\end{array}$ & $\begin{array}{r}\text { Thickness } \\
{[\mathrm{m}]}\end{array}$ & $\begin{array}{r}\text { Time } \\
{[\mathrm{ka}]}\end{array}$ & $\begin{array}{r}\text { Sedimentation rate } \\
{\left[\mathrm{m} \mathrm{kyr}^{-1}\right]}\end{array}$ \\
\hline Gudo, Gaggiolo Lungo (1) & $2718010 / 1114310$ & $\begin{array}{l}1.79 \\
2.26\end{array}$ & $\begin{array}{l}110 \\
600\end{array}$ & 0.47 & 0.49 & 0.96 \\
\hline Magadino, Castellaccio (2) & $2710790 / 1112340$ & $\begin{array}{r}5.85 \\
15.00 \\
49.70\end{array}$ & $\begin{array}{r}120 \\
980 \\
1860\end{array}$ & $\begin{array}{r}9.15 \\
34.70 \\
43.85\end{array}$ & $\begin{array}{l}0.86 \\
\\
0.88 \\
1.74\end{array}$ & $\begin{array}{l}39.43 \\
25.20\end{array}$ \\
\hline Carasso, Lusanico (3) & $2721800 / 1118300$ & 0.60 & 1250 & 0.60 & 1.27 & 0.51 \\
\hline Giubiasco (3) & $2721480 / 1114630$ & 0.45 & 850 & 0.45 & 0.87 & 0.52 \\
\hline Bellinzona, Archivio di Stato (4) & $2721460 / 1116970$ & - & 435 & 1.25 & 0.48 & 2.60 \\
\hline
\end{tabular}

MCRA modelling with other case studies modelled in the Lepontine Alps indicates lower values of the dry Coulomb-type friction (coefficient $\mu$ ) and higher values of the viscous turbulent friction (coefficient $\xi$ ) with respect to rockslide events of lower magnitude, which suggests a quick-running flow of the rock avalanche, probably determined by the high interaction of the fragmented rocks and the very high height difference (more than $1500 \mathrm{~m}$ ) between the detachment zone and the accumulation zone.
3. The damming of the valley floor exercised by the MCRA accumulation up to an elevation of $390 \mathrm{~m}$ a.s.1. allowed the creation of a lake which reached the maximum extent of $4.5 \mathrm{~km}$ and $130 \mathrm{hm}^{3}$. This damming was probably favoured by the silty sand matrix generated by the high interaction between the clasts during the rock avalanche falling, which allowed the accumulation to be partially impermeable to the water passage. The dam breaching at the time of the lake overflow caused an enormous flood, known as the Buzza di Biasca, characterized by a peak flow rate of 50000-60000 $\mathrm{m}^{3} \mathrm{~s}^{-1}$, decreasing progressively toward Lake Maggiore. 
4. The MCRA, the subsequent creation of Lake Malvaglia and the sudden collapse of the dam triggering the Buzza di Biasca can be considered a sedimentary cascade originating from two very high magnitude events. Although the direct impact on the sedimentation of the floodplain indicates very limited fluvial deposit input related to the Buzza di Biasca, the morphological effect of this event was evident in the floodplain in the following centuries. Among the most important effects are the migration of the Ticino river mouth from the south to the north, the rapid progradation of the Ticino river delta and the fluvial metamorphosis of the river Ticino from a meandering to a braided morphology. This indicates that the MCRA generated geomorphological consequences that affected the Ticino valley as far as Lake Maggiore.

5. The reconstruction of large historical rock avalanches such as the MCRA allows the parametrization and validation of numerical models, which can be applied to the forecasting of today's unstable zones that present similar geological and structural characteristics and have not already collapsed. These models are also significant for the correct interpretation of the chain of territorial consequences of large rockslides, affecting the valley floor (or even the lakes) located downslope of the sector directly impacted by the event. In this framework, they are of interest not only in the field of geosciences but also for a better comprehension of the historical and socioeconomic consequences of these major natural events.

Code availability. The code is not made accessible by the software developer because RAMMS::DEBRISFLOW is commercial software.

Data availability. Research data can be accessed through the SUPSI Instory (SUPSI INSTitutional repositORY), the online institutional archive of publications of the University of Applied Sciences and Arts of Southern Switzerland (SUPSI), at the following link https://repository.supsi.ch/13134/ (De Pedrini et al., 2021). All the further relevant data are included in the article.

Author contributions. Investigation and formal analysis for MCRA mapping and modelling were performed by ADP and supervised by $\mathrm{CA}$. Investigation and formal analysis for the MCRA geohistorical framework, as well as for Buzza di Biasca consequences, were performed by CS. ADP and CS prepared the manuscript with contributions from CA.

Competing interests. Cristian Scapozza is one of the two associated editors for the theme issue "Geomorphology and society". The peer-review process was guided by an independent editor, and the authors also have no other competing interests to declare.
Disclaimer. Publisher's note: Copernicus Publications remains neutral with regard to jurisdictional claims in published maps and institutional affiliations.

Acknowledgements. An anonymous source provided the translation from Latin of the document written by Giovan Battista Pellanda and the topographical map of Riviera in 1785 . The manuscript was substantially improved thanks to the two anonymous reviewers.

Review statement. This paper was edited by Nikolaus J. Kuhn and reviewed by two anonymous referees.

\section{References}

Ambrosi, C. and Scapozza, C.: Improvements in 3-D digital mapping for geomorphological and Quaternary geological cartography, Geogr. Helv., 70, 121-133, https://doi.org/10.5194/gh-70121-2015, 2015.

Bartelt, P., Bieler, C., Bühler, Y., Christen, M., Deunelbeiss, Y., Graf, C., McArdell, B., Salz, M., and Schneider, M.: RAMMS::DEBRIS FLOW User Manual v1.7.0, WSL Institute for Snow and Avalanche Research SLF, Davos, Switzerland, 109 pp., available at: https://ramms.slf.ch/ramms/downloads/ RAMMS_DBF_Manual.pdf (last access: 15 December 2021), 2017.

Bolla, P.: La storia di Olivone, Edizioni La Scuola, Bellinzona, Svizzera, 271 pp., 1931.

Bolla, S.: Olivone e i suoi dintorni. La scoperta delle Alpi bleniesi nell'iconografia e in un raro opuscolo di fine '800, Casagrande, Bellinzona, Svizzera, 149 pp., 1993.

Bolla, S.: Descrizioni della Valle di Blenio tra Settecento e Ottocento, Fondazione Voce di Blenio, Acquarossa-Dongio, Svizzera, 207 pp., 2010.

Bonnard, C.: Buzza di Biasca, Dictionnaire Historique de la Suisse (DHS), available at: https://hls-dhs-dss.ch/fr/articles/028662/ 2004-11-04/ (last access: 15 December 2021), 2004.

Bonnard, C.: Eboulements, Dictionnaire Historique de la Suisse (DHS), available at: https://hls-dhs-dss.ch/fr/articles/007783/ 2006-02-28/ (last access: 15 December 2021), 2006.

Brentani, L.: Antichi maestri d'arte e di scuola delle terre ticinesi: notizie e documenti, Tip. E. Cavalleri, Como, Italia, Vol. 1, 1937.

Claude, A., Ivy-Ochs, S., Kober, F., Antognini, M., Salcher, B., and Kubik, P. W.: The Chironico landslide (Valle Leventina, southern Swiss Alps): age and evolution, Swiss J. Geosci., 107, 273-291, https://doi.org/10.1007/s00015-014-0170-z, 2014.

Colombo, M.: Le strade tra Magadino e Biasca prima della nascita del Cantone Ticino, in: Atlante dell'edilizia rurale in Ticino, Locarnese, Bellinzonese, Riviera 1, edited by: Buzzi, G., Armando Dadò, Locarno, Svizzera, 283-301, 1999.

Cotti, G., Felber, M., Fossati, A., Lucchini, G., Steiger, E., and Zanon, P. L.: Introduzione al paesaggio naturale del Cantone Ticino. Tomo primo: le componenti naturali, Dipartimento dell'Ambiente, Bellinzona, Svizzera, 485 pp., 1990.

Christen, M., Bühler, Y., Bartelt, P., Leine, R., Glover, J., Schweizer, A., Graf, C., McArdell, B. W., Gerber, W., Deubelbeiss, Y., Feistl, T., and Volkwein, A.: Numerical simulation tool 
"RAMMS" for gravitational natural hazards, 12th congress INTERPRAEVENT, 10, Grenoble, France, January 2012.

De Antoni, S., Scapozza, C., Tognacca, C., Zucca, M., Bernasocchi, M., Bruni-Coduri, Y., and Chiaravalloti E.: La Buzza di Biasca attraverso le immagini e i documenti, 1515-2015, Comune di Biasca, Biasca, Svizzera, 127 pp., 2016.

De Pedrini, A., Ambrosi, C., and Scapozza, C.: The 1513 Monte Crenone rock avalanche: deposit topography data, SUPSI [data set], available at: https://repository.supsi.ch/13134/, last access: 23 December 2021.

Donati, P.: Notiziario archeologico ticinese 1968, Boll. Stor. Svi. It., 81, 50-78, 1969.

Donati, P.: Bellinzona, la Murata e la fortezza, in: Pierangelo Donati. Venticinque anni alla direzione dell'Ufficio cantonale dei monumenti storici, edited by: Foletti, G., Edizione Stato del Cantone Ticino, Bellinzona, Svizzera, 273-313, 1999.

Eisbacher, G. H. and Clague, J. J.: Destructive mass movements in high mountains: hazard and mitigation, Geol. Surv. Can., 84, 1230, 1984.

End, G.: Biasca und Val Pontirone. Eine Monographie aus den Tessinerbergen, Jahrb. Schweiz. Alpenclub, 57 (1922), 121-128, 58 (1923), 57-59, 1922-1923.

Franscini, S.: La Svizzera italiana, Volume Secondo, Parte II, Tipografia G. Ruggia \& Co., Lugano, Switzerland, 336 pp., 1849.

Galli, G.: Notizie sul Cantone Ticino: studio storico-politico e statistico, pubblicato sotto gli auspici della Società demopedeutica, Istituto Editoriale Ticinese, Bellinzona, Svizzera, 1616 pp., 1937.

Grossi, P.: Vita di un fiume. Consorzio correzione fiume Ticino dalla Moesa al Lago Maggiore 1886-1986, Salvioni, Bellinzona, Svizzera, 395 pp., 1986.

Gruner, U.: Bergstürze und Klima in den Alpen: gibt es Zusammenhänge?, Bull. angew. Geol., 11, 25-34, https://doi.org/10.5169/seals-226166, 2006.

Hantke, R.: Eiszeitalter. Die jüngste Erdgeschichte der Schweiz und ihrer Nachbargebiete. Band 3: Westliche Ostalpen mit ihrem bayerischen Vorland bis zum Inn-Durchbruch und Südalpen zwischen Dolomiten und Mont-Blanc, Ott Verlag, Thun, Schweiz, 730 pp., 1983.

Heim, A.: Bergsturz und Menschenleben, Vier. Natur. Gesell. Zürich, 20, 172-173, 1932.

Hungr, O. and Evans, S. G.: The occurrence and classification of massive rock slope failure, Felsbau, 22, 16-23, 2004.

Hungr, O., Evans, S. G., Bovis, M. J., and Hutchinson, J. N.: A review of the classification of landslides of the flow type, Environ. Eng. Geosci., 7, 221-238, https://doi.org/10.2113/gseegeosci.7.3.221, 2001.

Kienast, F.: Analysis of historic landscape pattern with a Geographical Information System - a methodological outline, Landscape Ecol., 8, 103-118, https://doi.org/10.1007/BF00141590, 1993.

Kündig, A. and Müller, B.: Topographical Map of Switzerland (Dufour Map), sheet OA 449 - Biasca, BI. XIX, Sect. 6, 1 : 50000, Swiss Federal Office of Topography swisstopo, 1854.

Kündig, A. and Müller, B.: Topographical Atlas of Switzerland (Siegfried Map), sheet 508 - Biasca, 1 : 50000, Swiss Federal Office of Topography swisstopo, 1881.

Lautensach, H.: Glazialmorphologische Studien im Tessingebiet, Teubner, Dresden, Deutschland, 69 pp., 1910.
Marazzi, S.: Atlante orografico delle Alpi: SOIUSA suddivisione orografica internazionale unificata del Sistema Alpino, Priuli \& Verlucca, Ivrea, Italia, 416 pp., 2005.

Montandon, F.: Eboulements alpins, Matériaux pour l'étude des calamités, 32, 271-340, 1933.

Motta, E.: La magia e la buzza di Biasca, Boll. Stor. Svi. It., 35, 4-7, 1915.

Nessi, G.-G.: Memorie storiche di Locarno fino al 1660, Tipografia di Francesco Rusca, Locarno, Svizzera, 207 pp., 1854.

OFEG: Instructions rédactionnelles pour la représentation des formes quaternaires et autres signes et symboles lors de la mise au net des cartes originales de l'Atlas géologique de la Suisse $1: 25^{\prime} 000$, Office fédéral des eaux et de la géologie (OFEG), Berne, Svizzera, 2003.

Pedrazzini, A., Jaboyedoff, M., Loye, A., and Derron, M. H.: From deep seated slope deformation to rock avalanche: Destabilization and transportation models of the Sierre landslide (Switzerland), Tectonophysics, 605, 149-168, https://doi.org/10.1016/j.tecto.2013.04.016, 2013.

Pellanda, C.: Memorie vallerane sulle orme di un cavaliere d'altri tempi, Salvioni, Bellinzona, Svizzera, 127 pp., 1991.

Piffaretti, P. and Luchessa, C.: Lo scorrere del fiume, l'opera dell'uomo. 125 anni di attività del Consorzio Correzione Fiume Ticino (1886-2011), Salvioni, Bellinzona, Svizzera, 164 pp., 2011.

Pometta, E.: La "buzza" di Biasca e le sue conseguenze, Boll. Stor Svi. It., 3, 105-112, 1928.

Prandi, E.: Studio sui depositi glaciali della Riviera, BSc Thesis, Università degli studi di Pavia, Pavia, Italia, 70 pp., 2018.

RAMMS rapid mass movements website: https://ramms.slf.ch/ ramms, last access: 8 May 2019.

Rossetti, G. P. and Rossetti-Wiget, M. E.: Biasca. Una comunità alpina nella memoria di una famiglia (1292-1992), Tipografia Jam, Prosito, Svizzera, 502 pp., 2013.

Salm, B.: Flow, flow transition and runout distances of flowing avalanches, Ann. Glaciol., 18, 221-226, https://doi.org/10.3189/s0260305500011551, 1993.

Salm, B., Gubler H. U., and Burkard, A.: Berechnung von Fliesslawinen: eine Anleitung für Praktiker mit Beispielen, Mitt. Eidg. Inst. Schnee- und Lawinenforschung, 47, 1-33, 1990.

Scapozza, C.: L'evoluzione degli ambienti fluviali del Piano di Magadino dall'anno 1000 a oggi, Arch. Stor. Ticin., 153, 60-92, available at: https://repository.supsi.ch/3155/ (last access: 15 December 2021), 2013.

Scapozza, C.: Appunti climatici e glaciologici sulle descrizioni della Valle di Blenio tra Settecento e Ottocento, Arch. Stor. Ticin., 155, 38-63, available at: https://repository.supsi.ch/5751/ (last access: 15 December 2021), 2014.

Scapozza, C. and Ambrosi, C.: Between glaciers, rivers and lakes: the geomorphological landscapes of Ticino, in: Landscapes and Landforms of Switzerland, edited by: Reynard, E., Springer Nature, Cham, Switzerland, 325-336, https://doi.org/10.1007/9783-030-43203-4_22, 2021.

Scapozza, C. and Oppizzi P.: Évolution morphosédimentaire et paléo-environnementale de la plaine fluviodeltaïque du Ticino pendant l'Holocène récent (Canton $\mathrm{du}$ Tessin, Suisse), Géomorphologie, 19, 265-286, https://doi.org/10.4000/geomorphologie.10289, 2013. 
Scapozza, C., Tognacca, C., Ambrosi, C., and Seno, S.: 20 maggio 1515: la "Buzza" che impressionò l'Europa, Boll. Soc. Ticin. Sci. Nat., 103, 78-88, available at: https://repository.supsi.ch/7111/ (last access: 15 December 2021), 2015.

Scapozza, C., Castelletti, C., and Czerski, D.: Nuove datazioni per la storia dell'evoluzione olocenica degli ambienti fluviali del Piano di Magadino (Cantone Ticino, Svizzera), Boll. Soc. Tic. Sci. Nat., 105, 97-102, available at: https://repository.supsi.ch/8625/ (last access: 15 December 2021), 2017.

Solari, R.: La bonifica del Piano di Magadino, Consorzio per la bonifica del Piano di Magadino, Bellinzona, Svizzera, 124 pp., 1982.

Stäuble, S., Martin, S., and Reynard, E.: Historical mapping for landscape reconstruction. Examples from the Canton of Valais (Switzerland), in: Mountain Mapping and Visualisation, Proceedings of the 6th ICA Mountain Cartography Workshop, La Lenk, Switzerland, 211-217, available at: http://www.mountaincartography.org/publications/papers/ papers_lenk_08/staeuble.pdf (last access: 15 December 2021), 2008.

Steinemann, S.: Simulation of rock mass failure runout with RAMMS. Short report: Simulation of the rock avalanche of Sasso Rosso, Airolo, 28 December 1898, Swiss Federal Research Institute WSL, Birmensdorf, Switzerland, 2012a.

Steinemann, S.: Simulation of rock mass failure runout with RAMMS. Short report: Simulation of the runout of the rock slope collapse of Preonzo in 2012, Swiss Federal Research Institute WSL, Birmensdorf, Switzerland, 2012b.
Steinemann, S.: Simulation of rock mass failure runout with RAMMS. Short report: Simulation of the runout of the rock slope failure in Val Canaria, 27 October 2009, Swiss Federal Research Institute WSL, Birmensdorf, Switzerland, 16 pp., 2012c.

Varnes, D. J.: Slope movement types and processes, Trans. Res. B., 176, 11-33, available at: http://onlinepubs.trb.org/Onlinepubs/sr/ sr176/176-002.pdf (last access: 15 December 2021), 1978.

Viganò, M.: Storie e cronache della Buzza di Biasca (30 settembre 1513-25 maggio 1515), Arch. Stor. Ticin., 154, 122-135, 2013.

Vom Rath, G.: Geognostisch-mineralogische Beobachtungen im Quellgebiete des Rheins, Z. Deut. Geol. Gesell., 1862, 369-532, 1862.

von Poschinger, A.: Large rockslides in the Alps: A commentary on the contribution of G. Abele (1937-1994) and a review of some recent developments, GSA Rev. Eng. Geol., 15, 236-255, https://doi.org/10.1130/REG15-p237, 2002.

von Poschinger, A.: The Flims rockslide dam, Bull. angew. Geol., 10, 407-421, https://doi.org/10.1007/978-3-642-047640_15, 2011.

Wiederkehr, M. and Möri, A.: swissALTI3-D - a new tool for geological mapping, Bull. angew. Geol., 18, 61-69, https://doi.org/10.5169/seals-391140, 2013. 